\title{
Situated learning for adults acquiring a second language ${ }^{1}$
}

\author{
Aprendizaje situado para adultos quienes adquieren una lengua \\ segunda \\ Rigoberto CASTILlo \\ Universidad Distrital Francisco José de Caldas \\ (Bogotá, Colombia) \\ Juan-Carlos VARGAS \\ Universidad Distrital Francisco José de Caldas \\ (Bogotá, Colombia)
}

\begin{abstract}
This article reports a case study of a group of English Language Learners involved in an outreach course which forms part of the social project Bogota Humana. To give meaning to learning another language (L2) the project held sessions inside and outside the classroom. The inquiry was directed on the perceptions of the local context and on its usefulness in L2 acquisition. It was found that outdoor spaces offer participants a sense of comfort which encourages participation and social interaction. They felt their identity, as adults and as citizens of the capital, was acknowledged.
\end{abstract}

Key Words: adult learning; second-language learning; situated learning, socio-cultural competence.

\section{Resumen}

Este artículo presenta un estudio de caso de un grupo de estudiantes del idioma inglés quienes participan en un curso de extensión que forma parte del proyecto social de Bogotá Humana. Para dar sentido al aprendizaje de otra lengua (L2) el proyecto realizó sesiones dentro y fuera del aula. La investigación fue dirigida por las percepciones del contexto local y de su utilidad en la adquisición de L2. Se encontró que los espacios al aire libre ofrecen a los participantes una sensación de confort que fomenta la participación y la interacción social. Ellos sintieron que su identidad, como adultos y como ciudadanos de la capital, fue reconocida.

Palabras Claves: educación de adultos; aprendizaje de segundas lenguas; aprendizaje situado; competencia sociocultural.

\footnotetext{
${ }^{1}$ The authors wish to thank Universidad Distrital professors Fabio Bonilla and Eliana Garzón, as well as alumna Linda Camelo, all of whom provided valuable feedback on previous versions of this article.
}

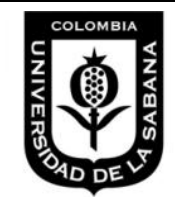

Castillo, R., \& Vargas, J. C. (2013). Situated learning for adults acquiring a second language. Latin American Journal of Content and Language Integrated Learning, 6(1), 20-36. doi:10.5294/laclil.2013.6.1.2 eISSN 2322-9721. 


\section{INTRODUCTION}

This paper reports on a case study with a class for adult learners of English, which forms part of the Bogota Mayor's office's strategy of human development in localities. The article frames the problem within the concepts of socio-cultural competence and of situated learning. The principles and procedures behind the pedagogical intervention, which consisted in combining classes with outings to tourist spots, are discussed. The results of the study suggest that adult second language (L2) acquisition benefits greatly from situated learning. The findings corroborate what Pratt (2005) proposes, that local culture discussions make learners aware of their capacity to transform their milieu.

\section{Problem}

In an effort to promote citizenship the program "Bogotá Humana" signed an agreement with an educational institution aimed at introducing low-income adults to English. At the start of the training, the adults were not very keen on devoting the time and effort required. Although they manifested interest in interacting and in living the L2, they seemed unwilling to engage in discussions. The tasks proposed did not seem to engage these beginners for they were prepared to study the language rather than use it.

The teacher saw the potentiality of using the L2 as a pedagogical tool to promote recognition of what adults know and to provide opportunities of learning more about their own community. Therefore, the teacher reduced the focus on the study of grammar and vocabulary; and engaged participants in re-discovering their city and their surroundings by combining formal instruction with visits and outings.

\section{Literature review}

Two constructs were considered: socio-cultural competence and situated learning. Socio-culturalism considers L2 learners as intercultural agents. For Byram and Zárate (1997), socio-cultural competence involves affective and cognitive dimensions. These authors argue that certain aspects of cultural competence are independent of linguistic competence and therefore for its study we need to resort to other disciplines. 
La relación a la alteridad en su dimensión a la vez afectiva y cognitiva, la toma en cuenta de la identidad del estudiante, la independencia de ciertos aspectos de la competencia cultural con respecto a la competencia lingüística nos llevan a privilegiar referencias disciplinarias hasta ahora poco utilizadas en la didáctica de las lenguas, tales como la antropología, psicología social y sociología. El estudiante de lenguas no tiene solamente un status socio-profesional sino que es definido como un sujeto socializado en una cultura dada. En ese sentido es un actor social. (p. 4)

The intercultural speakers gain awareness of their own language and culture as well as of the L2 and culture when they take on an L2. Arevalo (2009) also insists that the understanding of culture is crucial for L2 students to achieve L2 proficiency.

Socio-cultural competence involves the concept of perception of cultures. For Kramsch, (1993) language is an expression of personal meaning and a reflection of social order. Yet, she sees a difficulty since language and social reality are not coextensive. She highlights the dependency of this interaction on the context and how it is perceived by partakers, even when they share the same language. The way culture is presented in a specific territory, determines the way in which people perceive the world. In that sense, perceptions are the means by which inhabitants assume the "stimuli from the external world" (Singer, 1987, p. 9) in the way that they understand and interpret it.

The challenge of this program "Bogotá Humana" is to offer adults an L2 that is learnable and relevant to their everyday lives. Pratt (2004) considers Foreign language-learning (FL) as a means to social inclusion:

"Will most learners have a larger role to play in society because they know a foreign language? Probably not. But there are two other things to think about: one is power of succeeding at using an FL; and the second is access that successful use gives to global items such as the Internet, as well as to everyday FL in the society, such as brand names and control on electronic items. Ready access plus the power of success creates expectations and demands, on the part of the user, expectations and demands which pave the way to inclusion" (p.8).

The above concepts lead the way for the pedagogical intervention where culturespecific tasks and activities were proposed. These tasks attempted to maintain an environment that increased positive attitudes and perceptions in students to ensure effective instruction.

The second construct, situated learning, influenced the incorporation of visits as part of the pedagogical innovation. It was deemed that for making the 
classes inclusive it made sense to take into account the city - and its surroundingsas part of the course content. In the tasks, the adults' geographical location and their culture were treated, as social experiences which encouraged an authentic application of the language.

The goal of putting the L2 to use, of co-creating it with others and in settings that are relevant to the adults' life was coupled with Situated Learning which Brill (2001) explains as follows:

Regarded as leaders in the situated cognition movement, Lave and Wenger (1991), describe learning as an integral part of generative social practice in the lived-in world (p. 35). Their definition bears analysis: generative implies that learning is an act of creation or co-creation; social suggests that at least a portion of learning time occurs in partnership with others; and lived-in world connotes real-world practices and settings that make learning more relevant, useful, and transferable. From the standpoint of situated cognition proponents, foreign language acquisition will be more successful if the learners are immersed in conversational and cultural activities of increasing complexity and diversity, rather than concentrating on discrete-grammar exercises using recitation or paper-andpencil worksheets. (p.1)

The native speaker guests prepared presentations to be given on site, which was done in conjunction with the lead teacher-researcher. Situated Learning built rapport; and as Lantolf (2000) maintains "we use symbolic tools, or signs to mediate and regulate our relationships with others and with ourselves and thus change the nature of our relationships" (p. 75). Interest and diversity were some of the criteria for the visits which became a space of real-world practice. The background studied in class appeared in spontaneous interactions. The participants, in the role of visitors, were able to interact and learn from experts who worked in the sites as well as from more knowledgeable classmates not to mention from interacting with people who spoke English outside of class.

\section{METHODOLOGY}

\section{Research design}

The project was carried out in the south east of Bogota, benefitting 150 people whose age ranged between 17 and 65 years old. The project used a case study methodology with five participants. 
Figure 1. After Cohen, Manion, \& Morrison (2000, p. 101)

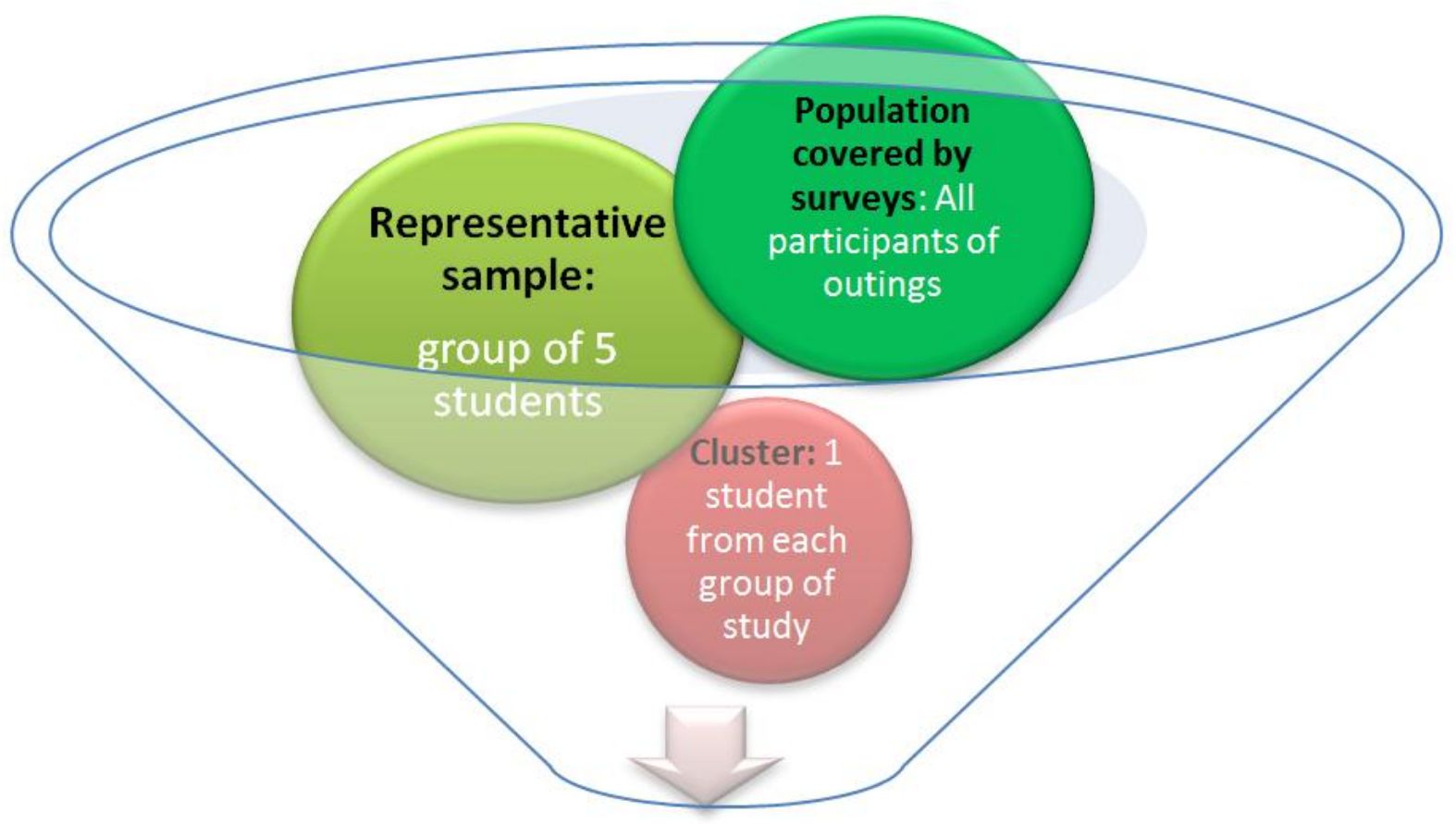

One of the aims of this case study was to explore the practical value of the intervention so as to offer relevant information regarding its efficacy (see Hammersley \& Gomm, 2000. p. 168). The intervention was carried out in fortyeight hours of instruction. The study used participant observation; teacher journals and reflective journals. A survey sought responses on perceptions, judgments and beliefs (Freeman, 1998, p. 77).

Table 1 summarizes the data collected from a sample of five students to respond to the question: How may the study of cultural content in Situated Learning contribute to L2 learning? 


\section{Table 1. Data collection process}

\begin{tabular}{|c|c|c|c|c|}
\hline $\begin{array}{l}\text { WHERE DOES THE DATA } \\
\text { COME FROM? }\end{array}$ & \multicolumn{2}{|c|}{ REFLECTIVE JOURNALS } & $\begin{array}{l}\text { STUDENTS' } \\
\text { ARTIFACTS }\end{array}$ & SURVEYS \\
\hline $\begin{array}{c}\text { WHAT CONSTITUTES } \\
\text { DATA? }\end{array}$ & TEACHER'S ACTIONS & $\begin{array}{l}\text { TEACHER'S } \\
\text { THOUGHTS }\end{array}$ & STUDENTS' ACTIONS & $\begin{array}{l}\text { STUDENTS' } \\
\text { THOUGHTS }\end{array}$ \\
\hline $\begin{array}{c}\text { WHAT CONSTITUTES } \\
\text { DATA? }\end{array}$ & $\begin{array}{c}\text { PLANING AND } \\
\text { CONDUCTING OUTINGS }\end{array}$ & $\begin{array}{l}\text { Journal \# } 1 \\
\text { Journal \# } 2 \\
\text { Journal \# } 3\end{array}$ & $\begin{array}{l}\text { Fieldwork, power points. } \\
\text { Photo sharing at } \\
\text { intercultural meetings } \\
\text { Videos in group } \\
\text { presentations. }\end{array}$ & $\begin{array}{l}\text { Survey \# } 1 \\
\text { Survey \# } 2 \\
\text { Survey \# } 3\end{array}$ \\
\hline \multicolumn{5}{|c|}{ WHEN WAS THE DATA COLLECTED? } \\
\hline $\begin{array}{l}\text { BEFORE OUTINGS (IN } \\
\text { CLASS) }\end{array}$ & Writing in journal & & $\begin{array}{l}\text { Graphic organizers and } \\
\text { Power Points. }\end{array}$ & Preliminary surveys \\
\hline DURING OUTINGS & Making video recordings & $\begin{array}{l}\text { Keeping anecdotal } \\
\text { records }\end{array}$ & Making Videos & \\
\hline $\begin{array}{c}\text { AFTER OUTINGS (IN } \\
\text { CLASS) }\end{array}$ & & Writing journal & Writing fieldwork & Final surveys \\
\hline
\end{tabular}

\section{Pedagogical intervention}

The inquiry aimed at understanding how a change of space would bring the L2 closer to natural communication incited the authors to use the city and its surroundings to promote the use of the target language in a context different from the classroom. As Castillo (2012) has argued: "The instruction received in classrooms may lag behind the education received in the environment. Meeting the present and the future needs of learners requires a revision of syllabi and of classroom practices" (p. v).

Before the outings, adults worked on authentic texts in English about the places. Outings were accompanied with one or more English speaking individuals. Citizenship was used as the carrier content when context was used to present the L2, as Evans and St John (1998, p.11) propose. The lesson plans dealt with language and cultural issues.

Before the visit, previous knowledge was activated and the language was worked on. For example the adults made a diagram to enumerate and correlate the 
problems of the city. A conversation club and interactive tasks also engaged them in language study and in cultural awareness.

Furthermore, real pictures were added to the Power Point presentations in order to activate their knowledge prior to visiting the preselected tourist spots. Reference to space and time relationships were made such as: "in the 20th century it used to be a cemetery"; "the park made part of the renovation of downtown"; "the sculpture donated by Botero constitutes a landmark". On the actual field trip the language of the task was used.

The teacher's knowledge of the learners and of the locations helped to tune in the tasks. English speaking guests gave oral presentations on site; which were prepared along with the lead-teacher.

Outings took place in Bogotá's old historical quarter, La Candelaria, in museums, and in libraries. The learners had gained confidence in the formal class sessions and on-site they were fully engaged in the topic and in the L2. They enjoyed interacting with others and tried hard at team work. Field trips included a hiking trip near the town of Villeta, 70 kilometers from Bogotá and rock climbing in the hills around Suesca, about 50 kilometers from Bogotá.

Back in the classroom students evaluated what they had learned about themselves, about the places and about L2 learning. For example they noticed that the local food item buñuelo could be described in, though not translated into, the L2. The students realized that first they needed to recall what it was made of and how it was made in order to be able to say that it is a small mass of fried or sautéed batter (a fritter).

One of the challenges for local outings that had to be addressed was to preservation of the "natural" use of the language when learners interacted among themselves and with the L2 speaking guests. For example, pragmatic issues on the adequacy of what to say to whom, was addressed. Appendix 1: Plan for a visit contains the schedule and the tasks proposed for an outdoor session.

\section{RESULTS}

\section{Data Analysis and categories}

The students' artifacts, such as written drafts, videos and pictures, provided the data on the acquisition of the L2 which was ingrained while dealing with local 
cultural content. For Hubbard and Miller (1999), an artifact "is tangible evidence of what kids [learners, in this case] are able to do, and of the range of responses kids make to different learning tasks" (p. 102). In addition, the teacher-researcher kept a journal with the observations of what happened inside and outside classroom boundaries.

The analysis of the data allowed the identification of three categories in response to the research question: "How may the study of cultural content in Situated Learning contribute to L2 learning?". These appear in Table 2 below.

Table 2. Categories of analysis

\begin{tabular}{|c|c|c|c|}
\hline CATEGORIES & $\begin{array}{l}\text { OUR SURROUNDINGS AS AN } \\
\text { INTERCULTURAL SETTING }\end{array}$ & $\begin{array}{c}\text { REFLECTION ON AND } \\
\text { INTERACTION WITH MILIEU }\end{array}$ & $\begin{array}{l}\text { REFERENCE TOTHE } \\
\text { PARTICIPANTS' } \\
\text { INTERACTION WITH } \\
\text { THE LOCAL } \\
\text { CONTEXT }\end{array}$ \\
\hline Patterns & $\begin{array}{l}\text { Approaching cultural knowledge } \\
\text { Participants acquired knowledge about } \\
\text { cultures in their vicinity. } \\
\text { Learners interacted with foreign visitors } \\
\text { and explored intercultural aspects }\end{array}$ & $\begin{array}{l}\text { Recognizing tourist places } \\
\text { Using tourism to foster integration } \\
\text { between communities }\end{array}$ & $\begin{array}{l}\text { Promoting social } \\
\text { integration with and in } \\
\text { their milieu. }\end{array}$ \\
\hline Related theory & $\begin{array}{l}\text { Socio-cultural aspects in EFL } \\
\text { communicative competence: } \\
\text { - } \quad \text { Zarate (1997). } \\
\text { - } \quad \text { Lantolf (2000). }\end{array}$ & $\begin{array}{l}\text { Means by which inhabitants assume the } \\
\text { "stimuli from the external world": } \\
\text { - } \quad \text { Singer (1987). } \\
\text { - } \quad \text { Rashed (2008). }\end{array}$ & $\begin{array}{l}\text { Spaces to develop the } \\
\text { participants' socio-cultural } \\
\text { competencies. } \\
\text { Promotion of the } \\
\text { recognition of territory as a } \\
\text { space of interaction } \\
\text { between communities: } \\
\text { - Mangubhai (2003). } \\
\text { - Cañas (2008). }\end{array}$ \\
\hline
\end{tabular}

Situated learning exercised a positive influence. Bearing in mind Kramsch's (1993, p. 9) suggestion about interaction of social reality and language in context, it is argued that the adults had the opportunity to use language according to their needs of expression as illustrated in the samples below in which they were asked to describe, in clauses, places that made Bogota an "open door city": 
Virgilio Barco Library: "Located in the middle of parks and sports complexes, the library designed by architect Rogelio Salmona has become an important cultural center of the city and a place where the Bogotanos can have fun.

Humedal Capellanía. "Wetland Capellanía" One of the natural and cultural places of Bogotá now has programs of action which allow citizens aware that care must be taken in places like this, there are nature walks led."

Additional samples can be found in Appendix 2: Hoja de ruta de jornada de inmersión.

In the outings, native speakers gave specific talks that related to the locals and their own culture. The adult learners spontaneously expressed they had assumed the role of intercultural speakers. They made attempts to interpret issues of the foreign culture while and after interacting with L2 speakers. Participants also construed some of the cultural aspects which characterize their local culture.

"The language can be used for giving directions or teach others about the city, and which are the places more representatives of Bogotá by your (sic) importance in the history of the country."

"It is very interesting, because you understand what attracts foreigners to Bogotá. Also, the trips are a help to lose the fear of speaking with foreigners." (Student D: Survey after Outing 1, 16 May 2012)

Testimonies suggest that while they were acquiring an L2 they learned about their own territory. They also evaluated L2 study as a means to acquire knowledge about themselves as well as about others.

"Me ha ayudado a profundizar más sobre el idioma. En el aprendizaje me ha cambiado la visión pues me ha fortalecido mis cualidades y he aceptado mis debilidades. En las salidas de campo como la de Suesca, aparte que no conocía el sitio me di cuenta que con actividades como la escalada y el club de conversación en inglés me puedo relacionar con otras personas." (Student C: Survey after Outing 2, 15 June 2012)

The content of teaching dealt with issues relevant to them. The participants expressed their thoughts and conferred with peers. Figure 2 is (adapted from) an excerpt from one of Student C's PowerPoint presentations talking about their neighborhood. 
Figure 2. Excerpt PowerPoint presentation

\begin{tabular}{|ll|}
\hline \multicolumn{1}{|c|}{ INDEX } \\
\hline & Localidad de Kennedy \\
1. & Banderas \\
2. & TransMilenio \\
3. & Parque Timiza \\
4. & Hacienda Las Palmas \\
5. & Corabastos \\
6. & Plaza de las Américas \\
7. & Mundo Aventura \\
"Kennedy is the location number eight of the Capital District \\
of Bogota, capital of Colombia. It is located to the \\
southwestern city. It stresses to be the most populated of the \\
city with more than one million inhabitants."
\end{tabular}

It was observed that learners saw themselves as active participants moving in a familiar territory. The dynamics of talking about and visiting a place engaged them in debates on what they saw or presented. They not only gained awareness on issues but most of the times came to conclude that social integration and collective solutions were needed.

Interviewer: Describe what Bogotá represents for you:

Interviewee: "Bogotá represents for I my city, because Bogotá is the city everybody. It's the place for live with opportunities in the work, the study. Its my Capital forever." (Student B: survey after outing 1 16/05/12)

The data suggests that the teacher and the participants evaluate situated learning as a process of participation in a community of practice. For Lave and Wenger (2005, p. 168) there is a relationship between the activities, their functions and the way they are understood by participants. The spaces visited brought discussions on citizenship connected to issues of economy, mobility and inequality, among other topics.

The impact of Situated Learning expands beyond the class. Learners manifested that they would like to return to the museum, to the library and to the other places with their friends or relatives. 
Which is the best way to know the city?

Student D: "to visit the places with the family. In family planning tours we can realize how beautiful is the city and know more about the history of some places". (Extracts from Survey No.2, 10 May 2012).

The teacher-researcher felt that the objectives of the program "Bogotá Humana" were better served by integrating the study of the local culture to the study of the L2 as in this journal excerpt.

Figure 3. Example of teacher reflective journal \#1, 02 April 2012.

La realización de la jornada de inmersión, logro contribuir con las políticas tanto distritales
como nacionales, en el reto de ubicar a Bogotá como primer destino turístico en el país, ya
que se enfoco al turismo como sector potenciador de desarrollo económico y de una mejor
imagen de la ciudad contando para ello con la institucionalidad de la gestión turística y la
política distrital de turismo con la responsabilidad de atender esta apuesta a través de los
espacios tanto académicos como laborales y del mismo modo hacer participes de la
propuesta a diferentes sectores de la ciudad, forjando procesos participativos e incluyentes,
buscando mejorar las formas de relacionarse con la ciudad.

There is a desire to make teaching more meaningful and more gratifying, based on the premise that the learning of English forms part of the overall education of the adults and the change of locations facilitated this endeavor.

\section{DISCUSSION}

In order to address the concerns a teacher and a group of adults had on finding meaning in studying the L2, the classroom routines were combined with conducting teaching in outdoor visits. It was necessary to look for ways of promoting shared knowledge "that encourages diversity of experience and reflection on that diversity" (Kramsch, 1993, p. 54).

The study met the objective of informing how L2 study could be enriched with local cultural content in Situated Learning. In response to the research question: "How may the study of cultural content in Situated Learning contribute to L2 learning?" the data suggests that the study of local cultural content in Situated Learning engaged the adults. The topics, the activities and the materials used in class gained more sense when experienced in spaces close to the learners' world.

At the same time, the contrasts of local and foreign cultural topics were found to provide the adults with new insights; it promoted adult literacy and 
awareness of their role as citizens. The reflections of both the English speaking guests and the class indicate that cultural identity and citizenship deserved attention.

The intercultural aspect, which is sometimes taken for granted in L2 courses, was deemed of great value. Learners realized that the L2 could be used to inform them and that Spanish could be transformed to report about something in English. Along those lines, the pedagogical innovation built on the fact that the adults have a rich experience with their own language, and an interest in how things work in the world.

As it can be imagined, the logistics, the time and the costs involved were an initial obstacle to move from a classroom to other spaces. When the teacher and the students saw the payoff they did not hesitate to come on board. Hopefully this article encourages practitioners not only to innovate, but also to conduct research on their practices.

\section{REFERENCES}

Arevalo, E. (2009). Assessing the development of learners' intercultural sensitivity and Intercultural Communicative Competence: The intercultural Spanish course. (Unpublished doctoral dissertation). University of Maryland, Baltimore, MD.

Brill, J. M. (2001). Situated Cognition. In M. Orey (Ed.), Emerging perspectives on learning, teaching, and technology. Bloomington, IN: Association for Educational Communications and Technology. Retrieved from http://projects.coe.uga.edu/epltt/index.php?title=Situated_Cognition

Byram, M., Nichols, A., \& Stevens, D. (2001). Developing intercultural competence in practice. Clevedon, England: Multilingual Matters.

Byram, M. \& Zarate, G. (1997). Definitions, objectives and assessment of sociocultural competence. In M. Byram, M., G. Zarate, \& G. Neuner (Eds.), Sociocultural competence in language learning and teaching (pp. 9-43). Strasbourg, France: Council of Europe.

Cañas, H. (2008). Fundamentación para el programa de inmersión en inglés en el tecnológico de Antioquia, Medellín.

Castillo, R. (2012). Editorial introduction: A reflection on the role of foreign language learning in today's education. Latin American Journal of Content 
and Language Integrated Learning, 5(2), iv-vii. doi:10.5294/laclil.2012.5.2.11

Cohen, L.; Manion, L., \& Morrison, K. (2003). Research methods in education (5th ed.). London, England: Routledge.

Dudley-Evans, T. \& St John, M. J. (1998.) Developments in English for specific purposes: A multi-disciplinary approach. Cambridge, England: Cambridge University Press.

Freeman, D. (1998). Doing teacher-research: From inquiry to understanding. Boston, MA: Heinle \& Heinle.

Gomm, R., Hammersley, M., \& Foster, P. (2000). Case study method: Key issues, key texts. Thousand Oaks, CA: Sage. doi:10.4135/9780857024367

Hubbard R. S., Shagoury, R. E.., \& Power, B. M. (2003). The art of classroom inquiry: A handbook for teachers-researchers (2nd ed). Portsmouth, NH: Heinemann.

Kramsh, C. (1993). Context and culture in language teaching. Oxford, England: Oxford University Press.

Lantolf, J. (2000). Sociocultural theory and second language learning. Oxford, England: Oxford University Press.

Lave, J., \& Wender, E. (2005). Practice, person and social world. In H. Daniels (Ed.), An introduction to Vygotsky (pp. 149-156). London, England: Routledge.

Mangubhai, F. (2005). What can EFL teachers learn from immersion language teaching? Asian EFL Journal, 7(4), 203-212.

Pratt, S. (2004). English for Brazilian adults: Inglés para o ensino de jovens $e$ adultos, pasaporte para inclusao social. Recife, Brazil: Edições Bagaço.

Pratt, S. (2005). Gravely pregnant with Freireian alternativity: Can foreign language learning avoid reinforcing cultural and social hegemony? $\mathrm{HOW}$, $12,9-17$.

Rashed, D. H. (2008). A case study of international ESL learners' perceptions of technology use in English language learning. (Unpublished M.A. dissertation). University of Maryland, Baltimore, MD.

Singer, M. R. (1987). Intercultural communication: A perceptual approach. Englewood Cliffs, NJ: Prentice-Hall. 


\section{APPENDIX 1: PLAN FOR A VISIT}

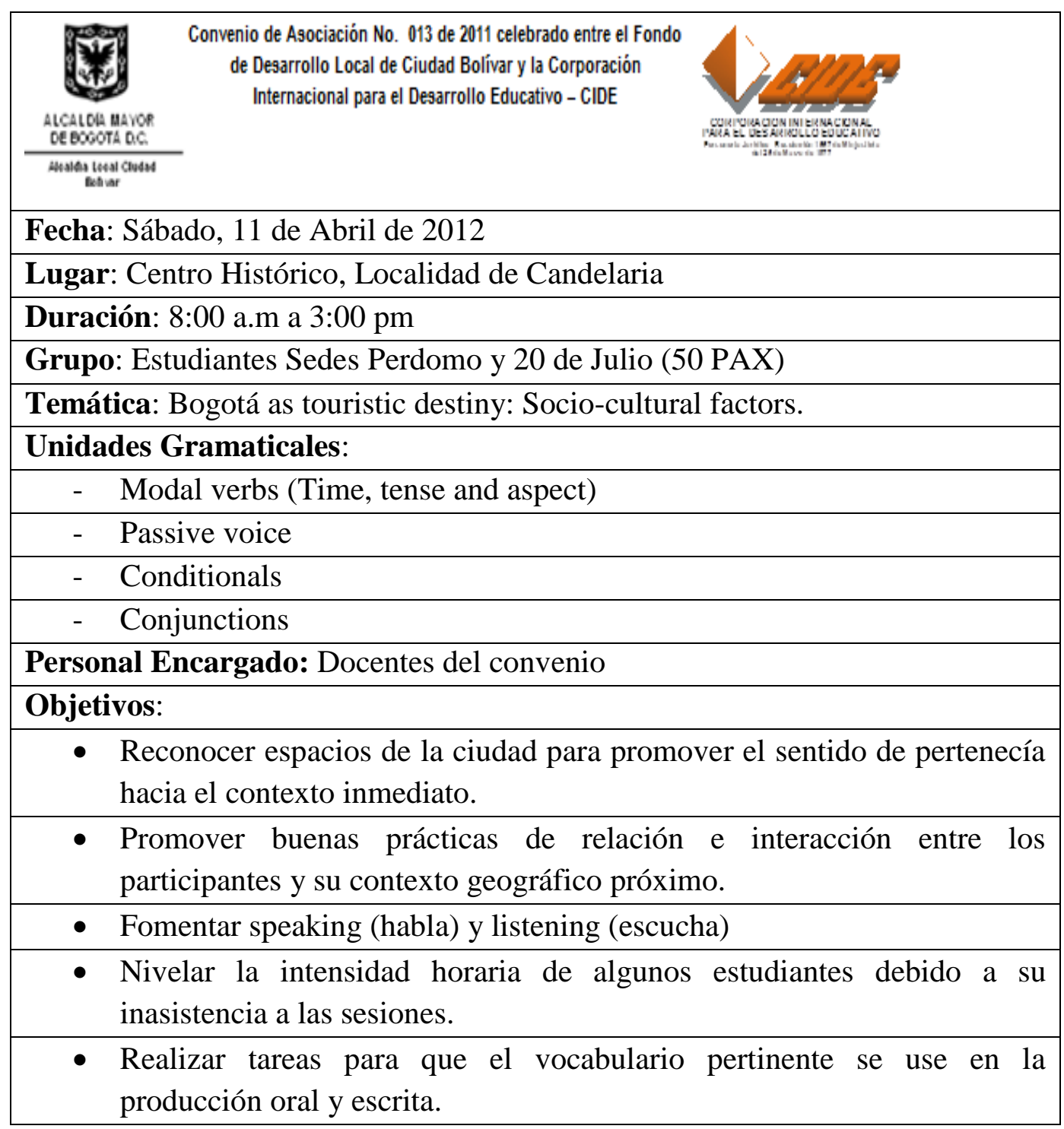




\section{APPENDIX 2: HOJA DE RUTA DE JORNADA DE INMERSIÓN}

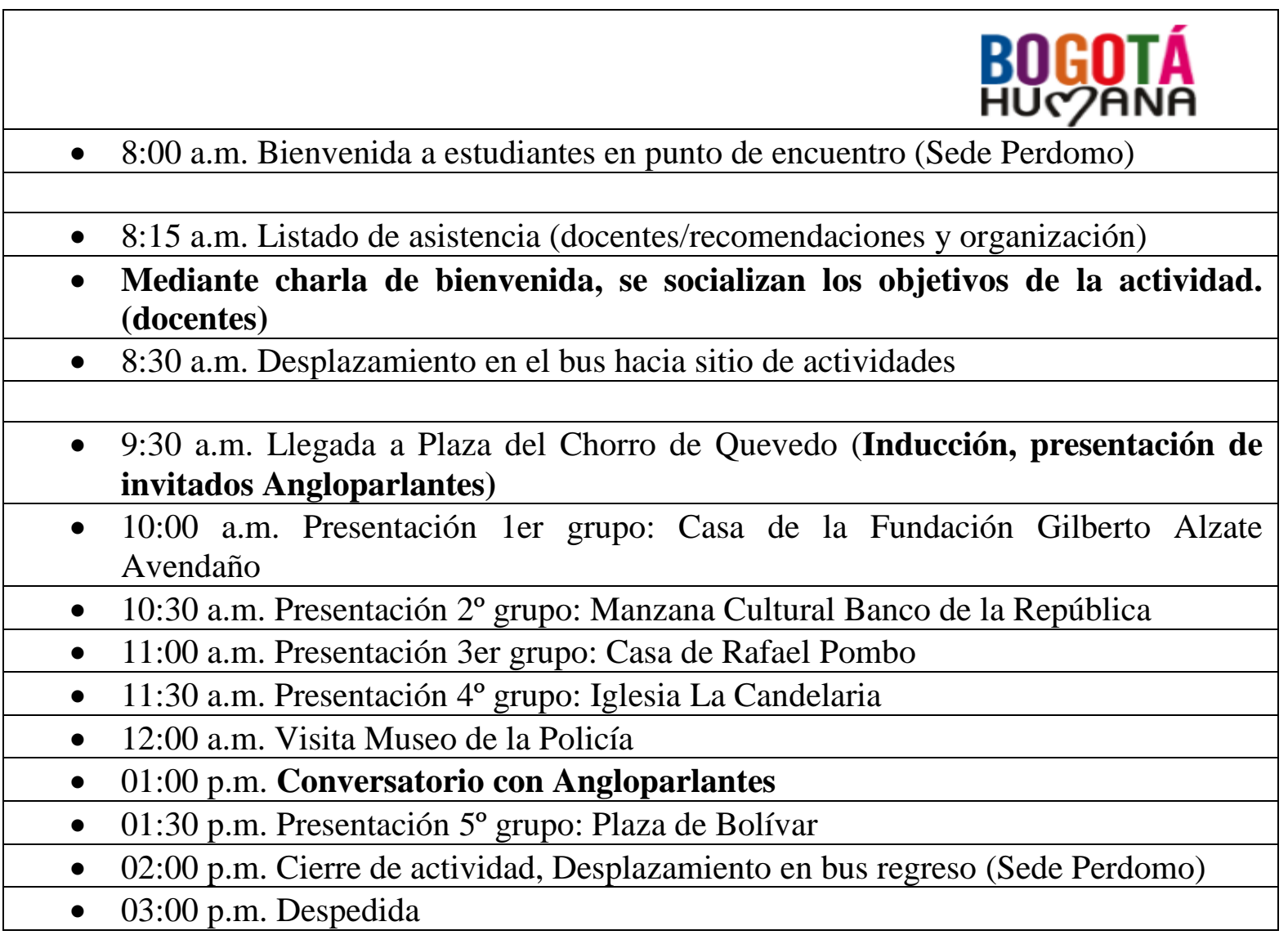




\section{APPENDIX 3: LANGUAGE PRODUCTIONS OF O.R.'S WORK GROUP 1}

BOGO-Á

UNIT: AN OPEN DOORS CITY Please elaborate a brief description of places that express the idea of Bogotá as an open doors city. Use relative clauses.

\section{Business}

\begin{tabular}{|l|l|}
\hline PLACE'S NAME & DESCRIPTION \\
\hline International center & $\begin{array}{l}\text { Commercial building where people meet to make business. } \\
\text { There are banks, shopping malls among others. }\end{array}$ \\
$\begin{array}{l}\text { Museo del Oro's } \\
\text { station }\end{array}$ & $\begin{array}{l}\text { Meeting point for people who sell and buy emeralds. Informal } \\
\text { business }\end{array}$ \\
\hline
\end{tabular}

\section{Culture}

\begin{tabular}{|l|l|}
\hline PLACE'S NAME & DESCRIPTION \\
\hline Monserrate & $\begin{array}{l}\text { Sanctuary: Located at 3,190 meters above the sea in the eastern } \\
\text { hills of Bogota, overlooking the city. There is a Catholic church } \\
\text { and the shrine "Señor Caido". Place of pilgrimage where people } \\
\text { go to pray and request favors from God. }\end{array}$ \\
Zona Rosa & $\begin{array}{l}\text { Zona Rosa, Park 93: A good place for shopping, good food and } \\
\text { fun where you will find many satisfactions. }\end{array}$ \\
\hline
\end{tabular}




\section{Libraries}

\begin{tabular}{|l|l|}
\hline PLACE'S NAME & DESCRIPTION \\
\hline National Library & $\begin{array}{l}\text { It is the oldest national library of America. Founded in 1777, } \\
\text { has in its collection 48 universal incunabula, about 30 } \\
\text { thousand books published before 1800, many rare and curious } \\
\text { books, how the first newspaper printed in Colombia and a } \\
\text { huge collection of cultural gems. }\end{array}$ \\
Virgilio Barco Library & $\begin{array}{l}\text { Located in the middle of parks and sports complexes, the } \\
\text { library designed by architect Rogelio Salmona has become an } \\
\text { important cultural center of the city and a place where the } \\
\text { Bogotanos can have fun. }\end{array}$ \\
\hline
\end{tabular}

\section{Nature}

\begin{tabular}{|l|l|}
\hline PLACE'S NAME & DESCRIPTION \\
\hline $\begin{array}{l}\text { Wetland "El Burro"' } \\
\text { (the donkey) }\end{array}$ & $\begin{array}{l}\text { Understanding that a wetland ecosystem is a compromise } \\
\text { between water and land which are also in danger of extinction. } \\
\text { There some species are in danger of extinction. }\end{array}$ \\
Wetland Capellanía & $\begin{array}{l}\text { This large wetland area is popular for bird watching, but people } \\
\text { living nearby have not recognized the ecological value it has. } \\
\text { One of the natural and cultural places of Bogotá now has } \\
\text { programs of action which allow citizens aware that care must } \\
\text { be taken in places like this, there are nature walks led. }\end{array}$ \\
\hline
\end{tabular}

\section{BIODATA}

Rigoberto Castillo holds a $\mathrm{Ph}$. D. in Foreign Language Education from the University of Texas at Austin. He teaches in the Doctorado Interinstitucional en Educación at the Universidad Distrital Francisco José de Caldas in Bogotá (Colombia). He has lectured and consulted for a number of organizations in Latin America. His book on strategic learning was nominated for the British English Language Teaching award (ELTons). He is a recipient of the National Award of the Colombian Association of Teachers of English.

Juan-Carlos VARGAS completed his course work for the B.A in TEFL at the Universidad Distrital. His thesis on situated learning was directed by Rigoberto Castillo. He has taught at a number of schools and currently teaches English to adults. 